\title{
THE PROBLEM OF ADAPTING EXISTING RESIDENTIAL BUILDINGS IN THE COUNTRY TO THE REQUIREMENTS OF ECOLOGY
}

\author{
Norbert DABKOWSKI ${ }^{1}$, Bożena PĘDZICH ${ }^{2}$ \\ ${ }^{1}$ Warsaw University of Life Sciences - SGGW, \\ Faculty of Civil and Environmental Engineering, Warszawa, Poland \\ ${ }^{2}$ Pabich Sp. z o.o. Przedsiębiorstwo budowlane, Ostrołęka, Poland
}

\begin{abstract}
The article presents the results of direct research on residential buildings and their modernization in selected ecological farms of the Mazovia region. The research area covered two poviats (counties) in the Mazowieckie Voivodeship: Makowski and Ostrołęcki. A total of 10 residential buildings on farms were examined. The study was conducted based on conversations with owners during on site visits.
\end{abstract}

Keywords: residential building, modernization, renovation, ecology

\section{INTRODUCTION}

The current level of informing society about the dangers connected with the unrestricted use of environmental resources is high, resulting in a so-called "sustainable development" policy.

The technology of producing building materials makes it possible to apply increasingly economical and ecological materials, as well as entire building systems used to construct buildings $[4,7]$. It seems perfectly natural that these issues should have a significant meaning in such places where ecology is placed first, i.e. organic farms. The question, therefore, arises: are the modernizations,

\footnotetext{
${ }^{1}$ Corresponding author: Warsaw University of Life Sciences - SGGW, Faculty of Civil and Environmental Engineering, Nowoursynowska st 159, 02-787 Warszawa, Poland, e-mail: norbert_dabkowski@sggw.pl,tel.+48225935121

${ }^{2}$ Corresponding author: Pabich Sp. z o.o. Przedsiębiorstwo budowlane, Bohaterów Westerplatte st 10, 07-410 Ostrołęka, Poland, e-mail: biuro@ pabich.com.pl
} 
additions and alterations to residential buildings located on organic farms, that is producers of certified organic food products, carried out with an understanding of sustainable building development? These issues were the subject of studies assumed by the author, as well as in other works $[3,4,5,6$, 8].

\section{CASE STUDIES}

The studies were carried out in the Northeastern Region of Mazowsze. Four farms are located in the Ostrołęcki county (poviat), i.e. Grale, Brzozowa, Łyse, and Łączki, with six in the Makowski county, i.e. Ogony, Różan, Młynarze.

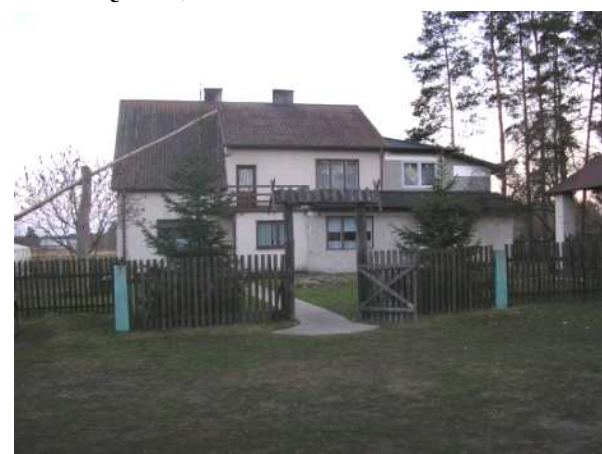

Fig. 1. Building on farm 1

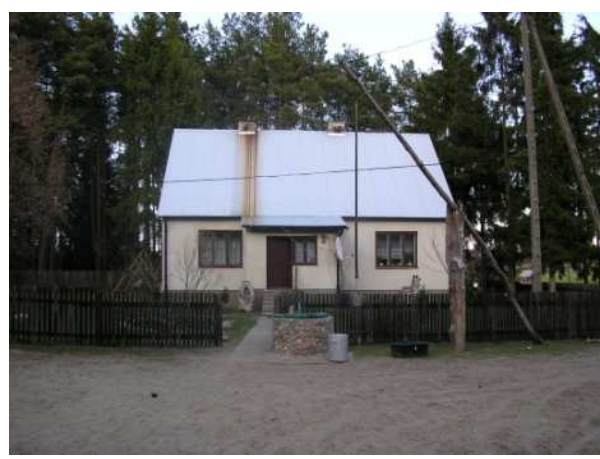

Fig. 3. Building on farm 3

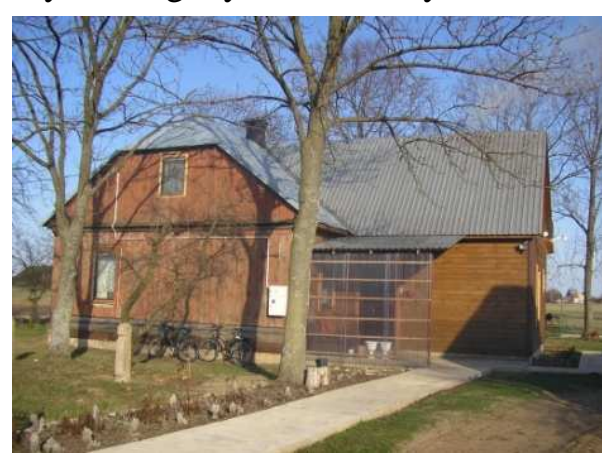

Fig. 2. Building on farm 2

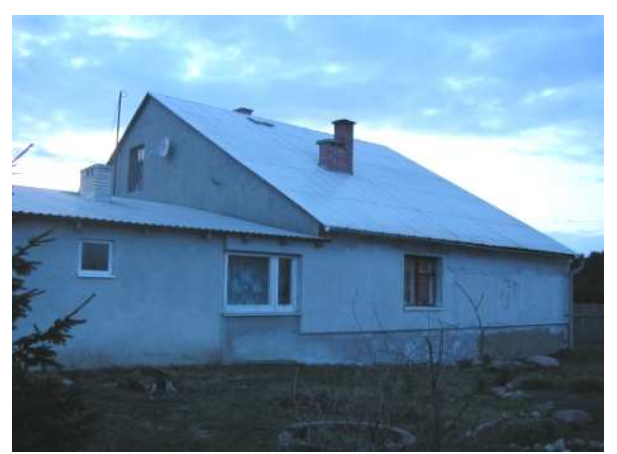

Fig.4. Building on farm 4

The analyzed farmhouses are located near main national roads. The size of the recreational properties ranges from 10 to 60 ares. Four of them are located on the edge of the village, among fields, meadows and forests, whereas the remaining farms are within villages, in the direct vicinity of other properties and buildings. Each of the properties contains buildings for agricultural production, at least one of which is covered by asbestos-cement tiles. All properties are 
connected to the electrical network, three of them to waterworks, and two of 10 to a sewerage network.

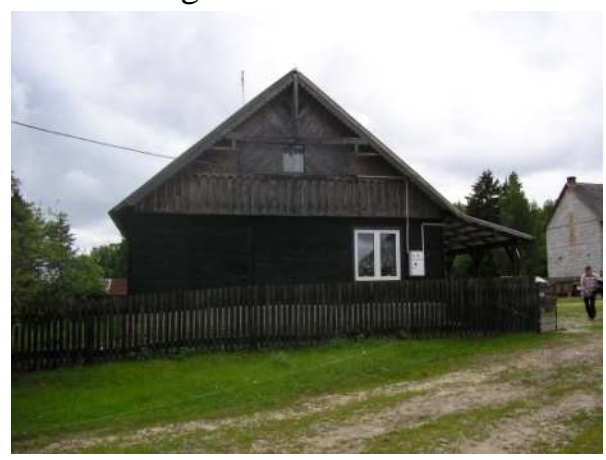

Fig. 5. Building on farm 5

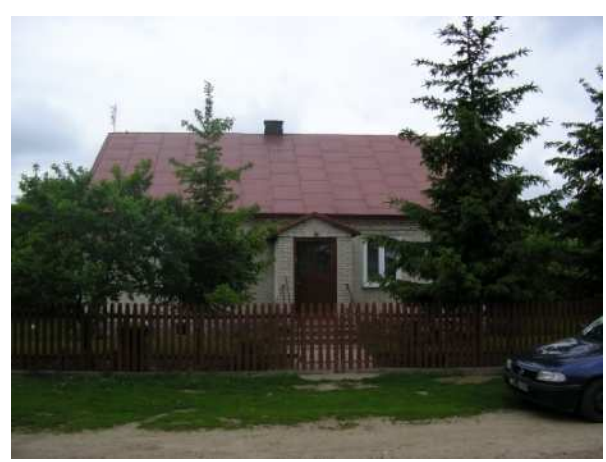

Fig. 7. Building on farm 7

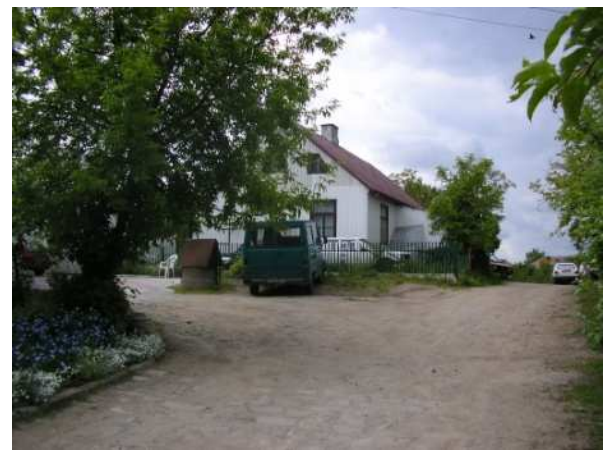

Fig. 9. Building on farm 9

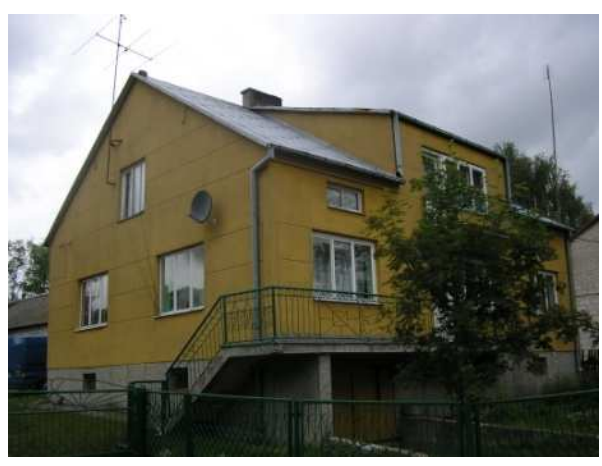

Fig. 6. Building on farm 6

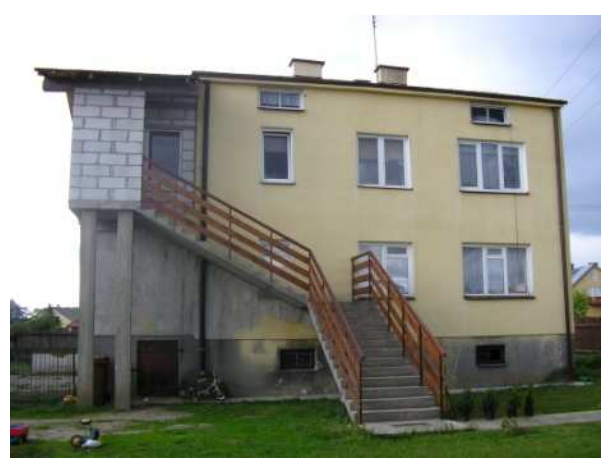

Fig. 8. Building on farm 8

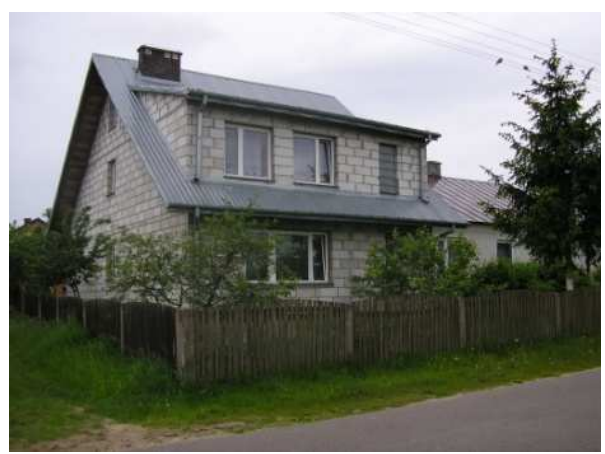

Fig. 10 Building on farm 10

In the scattered rural development, there is no network for the distribution of gas, therefore all of the houses are heated with fossil fuels - coal and firewood. Most of the properties are wooded, which creates a favorable microclimate in the summer (shade) and protects them from strong winds and blizzards in the 
winter. Each of the buildings has its own specific solutions for the ground floor layout, external walls, the connection of the roof cover.

Most houses are rather old (one is over 100 years old, 4 over 40, and 3 from the 80 's of the 20th century), with a surface area of 90 to $160 \mathrm{~m}^{2}$. Seven buildings were constructed in traditional brick technology, while three buildings employed wood technology. On the whole, the houses are characterized by an uncomplicated body of the building, with a partial or full basement and usable attic; in seven cases they have a compact shape with a rectangular layout, 2 are L-shaped, and a single building is built in the shape of the letter "T". The simple body of the buildings makes it possible to heat them appropriately (low energy requirements). Nine of the buildings are single-storey, with six containing a usable attic, and three without. One of the buildings is a 2-storey house with a usable attic.

The canon of traditional construction in the country, drawing on knowledge passed on from generation to generation, was the proper placement of the buildings on the land property in terms of directions. In the present analysis, as many as $90 \%$ of the buildings are situated unfavorably. The longer wall is not placed along the east-west axis, which makes it impossible to passively take advantage of the sun's energy. Most of the masonry buildings were constructed employing a double-layer outside wall. The materials used to build the outside walls in the presented buildings varied. Inside walls were usually built from different kinds of ceramic brick and wood material constructions. All of the buildings have wooden trusses; the roof covering of nine of the buildings are various forms of sheet metal (flat sheets, metal roofing tile, and trapezoidal sheets).

Modernization and/or renovation works were carried out on six of the analyzed buildings. Two of the buildings had been added onto - in Building 1, an area for servicing tourists was added (rooms, bathrooms, etc.), whereas in Building 2, the living area was increased. Renovation work involved replacing the construction and covering of the roof, as well as insulating the walls. Two older buildings were insulated (Buildings 2 and 5), the roof covering was changed in one (Building 3). In one of the buildings, the entrance area was modernized, dividing the upstairs and downstairs into two separate parts (Building 10). The additions, renovations and modernizations were carried out using materials which were available during the modernization works or ones gathered earlier; this had various causes - a lack of awareness regarding the necessity to create an ecological living area, the lack of possibilities to obtain appropriate materials, etc. The remaining buildings, i.e. $40 \%$ of those covered by the study, did not undergo any renovations from the time they were built. Houses built in the eighties of the past century are treated as relatively new and remain in an 
unchanged state, merely renewing the interiors. This is followed by various forms of insulating the outside walls (styrofoam, mineral wool in boards); other times, it is completely non-existent. Four of the buildings have insulated outside walls, with one building (No. 4) insulated by means of the light wet method using styrofoam. Building 2 was insulated when the building was added onto, using the dry light method with mineral wool boards. Building 5 is insulated from the inside with boards of mineral wool installed when renovating the interior. As one of few, Building 8 has styrofoam isolation inside a three-layer wall. As indicated by the studies [2], vertical partitions may not meet the requirements of norms even in the case of buildings which had undergone thermo modernization, thus the temperature comfort within the rooms is insufficient.

The ceilings in all building are insulated, though in the majority of them the insulation layer comprises of woodchips or slag. Mineral wool or styrofoam insulation is present in $40 \%$ of the buildings - the two newest ones (4 and 8), as well as two wooden buildings which had undergone thermomodernization (2 and 5). Two buildings have an insulated roof - a flat roof and a roof over a usable attic. The insulation is of mineral wool.

In some buildings, bathrooms were sectioned off during remodeling works; they thus occupy rooms which were originally meant to serve a different function. This resulted in a not very functional layout of the bathrooms (location with an entrance from the porch or directly from a room).

\section{CONCLUSIONS}

As found in the studies, the thermal comfort inside the buildings may be insufficient, while employing the cheapest source of fuel for heating (coal and wood) has a negative impact on the environment. In the analyzed buildings modernization work was not carried out on the heating systems in order to reduce the harmful effect of burning fossil fuels on the environment; what is more, no solutions for using renewable energy are present.

The quality of material solutions of the buildings and/or their modernization and expansion has a negative impact on the comfort of living, not to mention the ecological development of the living environment. When selecting the materials used to add on to the building or carry out modernization or remodeling works, the ecological development of the building was not taken into account, instead using traditional materials, not always of good quality, available on the market. The majority of modernization or renovation works were carried out prior to taking on ecological farming activity, which was also observed in the work [1]. 
The studies show that there are no connections between running an ecological farm and an ecological living environment of its inhabitants. On the whole, the farm owners do not see the need for applying a pro-ecological heating system or properly insulating their buildings. However, the benefits of such solutions are understood and backed by those running ecological farms connected with agrotourism $^{3}$.

The problem of asbestos-cement tile roof covering occurred in one or a few buildings on each of the analyzed farms, and ought to be resolved in the entire country by $2032^{4}$. However, in the case of ecological farms, these types of actions should in fact be accelerated. In the light of laws regulating the energy pattern of buildings ${ }^{5}$, as well as the changing (reduced) in subsequent ordinances ${ }^{6}$, i.a. heat transfer coefficient, one can count on further renovations and modernizations being carried out properly.

From the point of view of proecological activities, one should strive so that all types of renovations and modernizations of buildings, not only residential, located on a farm focused on production using ecological methods take place using materials currently considered to be ecological and energy efficient.

\section{REFERENCES}

1. Dąbkowski N., 2002, Nieekologiczne zabudowania $w$ ekologicznych gospodarstwach, Problemy Rozwoju Budownictwa, $\mathrm{nr}$ 1, Instytut Gospodarki Mieszkaniowej, Warszawa

2. Dąbkowski N. Matuszewicz K., 2010, Analiza cieplna zewnętrznych przegród pionowych $w$ budynkach mieszkalnych wybranych gospodarstw ekologicznych $w$ województwie podkarpackim, ACTA Scientiarum Polonorum, seria Architectura, nr 9, Warszawa

3. Kania S., Musiał W., Suwalski J., Zwierzchowska Z., 1997, Nieekologiczne „ekologiczne” rozwiazania konstrukcyjne w budownictwie, [w:] materiały IX Ogólnopolskiej Interdyscyplinarnej Konferencji Naukowo - Technicznej „Ekologia a Budownictwo”, UW Bielsko - Biała, ITB, Politechnika Krakowska, PZITB, Bielsko - Biała,

\footnotetext{
${ }^{3}$ conversations with owners during on site visits

${ }^{4}$ In accordance with the Program of Asbestos Removal for years 2009-2032, http://www.mg.gov.pl/Bezpieczenstwo+gospodarcze/Program+Oczyszczania+Kraju+z+ Azbestu

${ }^{5}$ Act of 29 August 2014 on the energy pattern of buildings (Dz. U. 2014 item. 1200)

${ }^{6}$ Ordinance of the Minister of Infrastructure of 12 April 2002 on the technical conditions which should be met by buildings and their location (Dz. U. 2002 No. 75 item 690 as amended)
} 
4. Mikoś J., 2002, Budownictwo ekologiczne, Wyd. Politechniki Śląskiej, Gliwice

5. Mikoś - Rytel W., 2000, O architektonicznym ksztattowaniu ekologicznych budynków mieszkalnych, [w:] materiały XII Ogólnopolskiej Interdyscyplinarnej Konferencji Naukowo - Technicznej Ekologia a Budownictwo", Śląski UW, ITB, Politechnika Krakowska, PZITB, Bielsko - Biała, ,

6. Róg Z., 1993, Ekologiczne podstawy ksztattowania miejskich jednostek osadniczych, [w:] materiałach Krajowej Konferencji „Zdrowy Dom. Dom Promujący Zdrowie", Centrum Organizacji i Ekonomiki Ochrony Zdrowia, Zakład Promocji Zdrowia, Politechnika Warszawska, Wydział Architektury, Warszawa,

7. Stawicka-Wałkowska M., 1998, Dostosowanie budownictwa i przemystu materiałów budowlanych do założeń zrównoważonego rozwoju, X Ogólnopolska Konferencja Naukowo-Techniczna Ekologia a Budownictwo, Bielsko-Biała

8. Sumień T., Wegner-Sumień A., 1990, Ekologiczne miasta, osiedla i budynki, Instytut Gospodarki Przestrzennej i Komunalnej, Warszawa.

\section{PROBLEM DOSTOSOWANIA ISTNIEJACCYCH BUDYNKÓW MIESZKALNYCH NA WSI DO WYMOGÓW EKOLOGICZNYCH}

\section{Streszczenie}

W artykule przedstawiono wyniki badań bezpośrednich dotyczących budynków mieszkalnych i ich modernizacji w wybranych gospodarstwach ekologicznych Mazowsza. Jako obszar badawczy wybrano powiaty województwa mazowieckiego: makowski i ostrołęcki. Przebadano łącznie budynki mieszkalne w 10 gospodarstwach. Badania przeprowadzono opierając się na wizji lokalnej i rozmowach z właścicielami.

Słowa kluczowe: budynek mieszkalny, modernizacja, remont, ekologia 
